\title{
Oral Chelation Therapy for Cadmium Poisoning with Cd(II)- MAC Imprinted pHEMAC Nanoparticles
}

\section{Kadmiyum Zehirlenmesinde Oral Şelasyon Tedavisi için Cd(II)- MAC Baskılanmış pHEMAC Nanoparçacıkları}

\author{
Research Article
}

Mitra Jalilzadeh, Duygu Çimen, Handan Yavuz, Adil Denizli*

Department of Chemistry, Biochemistry Division, Hacettepe University, Ankara, Turkey.

\section{A B S TR AC T}

\begin{abstract}
I this study, $\mathrm{Cd}(\mathrm{II})$ ) ions imprinted poly(hydroxyethyl methacrylate- $\mathrm{N}$-methacryloyl-(L)-cysteine methylester) pHEMAC nanoparticles was prepared for the oral treatment of heavy metal poisoning. Cd(II) ions imprinted pHEMAC nanoparticles were characterized by transmission electron microscopy (TEM), Fourier transform infrared spectroscopy (FTIR), zetasizer, and surface area calculations. The efficiency and selectivity of these $\mathrm{Cd}(\mathrm{II})$ ions imprinted pHEMAC nanoparticles were investigated both in deionized water and simulated gastrointestinal fluids. Adsorption studies were performed at different $\mathrm{pH}$, temperature and initial concentrations of $\mathrm{Cd}(\mathrm{II})$ ions to determine optimum conditions. The selectivity studies were accomplished with $\mathrm{Cd}(\mathrm{II})$ ions imprinted and non-imprinted pHEMAC nanoparticles by using different metal ion solutions (i.e., copper, zinc, nickel, and lead ions). Langmuir and Freundlich isotherms were applied for these adsorption studies.
\end{abstract}

\section{Key Words}

Cadmium, nanoparticles, molecular imprinting.

\section{öz}

u çalışmada, ağır metal zehirlenmesinin ağıdan tedavisi için Cd(II) iyonları baskılanmış poli(hidroksietilmetakrilat-N-metakriloil-(L)-sisteinmetilester) pHEMAC nanopartikülleri hazırlanmıştır. Cd(II) iyonları baskılanmış pHEMAC nanopartikülleri geçirimli electron mikroskobu (TEM), Fourier Dönüşümlü Infrared Spektrofotometre (FTIR), zetasizer ve yüzey alanı hesaplamaları ile karakterize edilmiştir. Cd(II) iyonIarı baskılanmış pHEMAC nanopartiküllerin etkinliği ve seçiciliği, hem deiyonize su hem de simüle edilmiş midebağırsak sıvılarında incelenmiştir. Optimum koşulları belirlemek için farklı pH, sıcaklık ve Cd(II) iyonlarının farklı derişimlerinde çözeltiler hazırlanarak adsorpsiyon çalışmaları yapılmıştır. Seçicilik çalışmaları, farklı metal iyon çözeltileri (yani bakır, çinko, nikel ve kurşun iyonları) kullanılarak Cd(II) iyonları baskılanmış ve baskılanmamış pHEMAC nanopartikülleri ile gerçekleştirilmiştir. Adsorpsiyon çalışmaları için Langmuir ve Freundlich izotermleri uygulanmıştır.

\section{Anahtar Kelimeler}

Kadmiyum, nanopartiküller, moleküler baskılama.

Article History: Received: Apr 5, 2018; Revised: May 31, 2018; Accepted: Sep 24, 2018; Available Online: Nov 13, 2018. DOI: 10.15671/HJBC.2018.258

Correspondence to: A. Denizli, Department of Chemistry, Biochemistry Division, Hacettepe University, Ankara, Turkey. 


\section{INTRODUCTION}

admium ( $\mathrm{Cd}(\mathrm{II}))$ is widely dispersing in air, soil or water by mining or smelting activities. The human body can take cadmium from air, water or soil. $\mathrm{Cd}(\mathrm{II})$ ions that released into the atmosphere is deposited on the earth by rain. This metal is also used mainly in phosphate fertilizers, sewage sludge, metal-plating, pigments production, NiCd batteries, plastic's stabilizers, and nuclear reactors. $\mathrm{Cd}(\mathrm{II})$ ions in water and soil are included into the food chain by plants, then animals and humans [1]. The rice because of the high potential of $\mathrm{Cd}(\mathrm{II})$ ions adsorption and accumulation is one of exposure to $\mathrm{Cd}(\mathrm{II})$ ions in the human body [2]. Also contaminated tea during growth transportation, packaging, and processing is one of another source of exposure to cadmium [3]. Cd(II) ions don't have any basic biological function in human bodies. The U.S. Environmental Protection Agency (EPA) categorizes this metal as the 126th of primary pollutants. This metal is similar with zinc element in chemical properties, that's why $\mathrm{Cd}(\mathrm{II})$ ions can replace with zinc, which is an essential trace element for many plants, animals, and microorganisms. $\mathrm{Cd}(\mathrm{II})$ ions also acts as an enzyme inhibitor. The biological half-life of $\mathrm{Cd}(\mathrm{II})$ ions is $10-35$ years in human body. $\mathrm{Cd}$ (II) ions affects all systems in the human body negatively and causes some health problems such as kidney damage, cardiovascular disease, infertility and high blood pressure. In addition, cadmium affects prostate function, testosterone levels, bone, renal, dopaminergic systems in children and nervous system that causes attention and memory decreasing in humans. The risks of $\mathrm{Cd}(\mathrm{II})$ ions accumulate in the human body are recognized by the International Agency for Research on Cancer and classified as the group 1 carcinogen [3]. $\mathrm{Cd}(\mathrm{II})$ ions polluted food is the main reason of $\mathrm{Cd}(\mathrm{II})$ ions exposure in the body for non-smokers [4-8]. The limit for $\mathrm{Cd}(\mathrm{II})$ ions levels in blood in the United States for healthy non-exposed, nonsmokers is 0.4 micro grams per liter $(\mu \mathrm{g} / \mathrm{L})$ (CDC 2005) [1]. Molecular imprinting technology (MIT) or ion imprinting technology (IIT) have an ability to recognize a certain molecule or ion according to shape, size and chemical functionality [9]. In addition, imprinted polymers because of their high selectivity to the target ion due to the affinity of the ligand are more effective [10]. Bioanalytical,
Environmental, food, and pharmaceutical science researcher is used MIPs or IIPs widely as affinitybased separation media [11]. Because of their unparalleled properties as large surface area and diffusion ability, nanoparticles are applied in many various areas for example; medicine, engineering, catalysis, and environmental remediation. Nanoparticles are used widely in medicine for drug delivery, organ imaging and killing of tumors via hyperthermia. The removal of $\mathrm{Cd}(\mathrm{II})$ ions from aqueous medium and human plasma were done by different adsorption materials like P(HEMA-EGDMA)-Cibacron Blue F3GA-thionein microspheres; the maximum amount of removing $\mathrm{Cd}(\mathrm{II})$ ions was $38.8 \mathrm{mg} / \mathrm{g}$ [12] from human plasma, $\mathrm{Cd}(\mathrm{II})$ ions imprinted P(HEMA-MAC) beads; the maximum capacity of $\mathrm{Cd}(\mathrm{II})$ ions adsorption capacity was $32 \mu \mathrm{mol} \mathrm{Cd}(\mathrm{II}) / \mathrm{g}$ beads [13] from human plasma, $\mathrm{Cd}(\mathrm{II})$ ions imprinted $\mathrm{p}$ (HEMAMAC) monoliths; the maximum capacity $\mathrm{Cd}(\mathrm{II})$ ions adsorption was $26.6 \mu \mathrm{mol} / \mathrm{g}$ from human plasma [14], P(EGDMA-VIM) hydrogels; these hydrogel maximum adsorption capacity for $\mathrm{Cd}(\mathrm{II})$ ions was $69.4 \mathrm{mg} / \mathrm{g}$ from aqueous medium [15], P(EGDMAVATZ) magnetic beads; the maximum capacity of $\mathrm{Cd}(\mathrm{II})$ ions adsorption was $134.9 \mathrm{mg} / \mathrm{g}$ of aqueous solution [16], Cd(II) ions imprinted P(HEMA-MAC) cryogels; the maximum adsorption capacity was $86.7 \mathrm{mg} / \mathrm{g}$ of aqueous solution [17]. In this study, our purpose was to prepare $\mathrm{Cd}(\mathrm{II})$ ions imprinted PHEMAC based nanoparticles for the oral treatment of $\mathrm{Cd}(\mathrm{II})$ ions poisoning in human. Cd(II) ions imprinted nanoparticles were selected because of their large surface area and their selective separation properties. For synthesizing of $\mathrm{Cd}(\mathrm{II})$ ions imprinted pHEMAC nanoparticles two-phase mini-emulsion polymerization method was used. After the characterization studies Cd(II) ions adsorption and selectivity experiments were performed in artificial gastric fluids.

\section{MATERIALS and METHODS}

HEMA (2-hydroxyethyl methacrylate), PVA (poly vinyl alcohol), MBAAm ( $\mathrm{N}^{\prime} \mathrm{N}^{\prime}$ methylene bisacrylamide, SDS (sodium dodecyl sulfate), ammonium persulfate, L-cysteine hydrochloride, methacryloyl chloride, sodium persulfate, L-cysteine hydrochloride, sodium bicarbonate, sodium bicarbonate, sodium bisulfite, and metal nitrates $\left(\mathrm{Cd}\left(\mathrm{NO}_{3}\right)_{2}, \mathrm{Cu}\left(\mathrm{NO}_{3}\right)_{2}, \mathrm{~Pb}\left(\mathrm{NO}_{3}\right)_{2}, \mathrm{Ni}\left(\mathrm{NO}_{3}\right)_{2}\right)$ 
were provided from Sigma Co. (St Louis, USA). EGDMA (Ethylene glycol dimethacrylate) was provided from Fulka A.G. (Buchs, Switzerland). Other chemicals were supplied from Merck A.G. (Darmstadt, Germany).

\section{Preparation of Pre-complex (Cd(II)-MAC)}

Cd(II):MAC (1:1) pre-complex was synthesized with the following procedure: $0.1 \mathrm{mmol}$ (18.9) of MAC was dissolved in $5.0 \mathrm{~mL}$ ethanol, then was added to $0.1 \mathrm{mmol}\left(30.8 \mathrm{mg}\right.$ ) of $\mathrm{Cd}\left(\mathrm{NO}_{3}\right)_{2} \cdot 4 \mathrm{H}_{2} \mathrm{O}$ at $25^{\circ} \mathrm{C}$. This mixture was magnetically stirred for $3 \mathrm{~h}$, then, centrifuged at $8000 \mathrm{rpm}$ for $1 \mathrm{~h}$. To separate the complex, the complex filtrated. The separated complex was washed by water-ethanol solution (50:50, v/v), and dried under vacuum (12 h, 200 $\mathrm{mmHg})$.

\section{Synthesize of Cd(II) lons Imprinted and Non-Imprinted pHEMAC Nanoparticles}

$\mathrm{Cd}(\mathrm{II})$ ions imprinted pHEMAC nanoparticles were synthesized by polymerization method of mini-emulsion two-phase [18]. For this method two aqueous phase and one organic phase were prepared: for first aqueous phase, $187 \mathrm{mg}$ of PVA, $28 \mathrm{mg}$ of SDS and $23.4 \mathrm{mg}$ of sodium bicarbonate were dissolved in $10 \mathrm{~mL}$ deionized water, for second aqueous phase $100 \mathrm{mg}$ PVA, and 100 $\mathrm{mg}$ SDS was dissolved in $150 \mathrm{~mL}$ of deionized water, for organic phase $4 \mathrm{~mL}$ of monomer 1 was dissolved in $2.1 \mathrm{~mL}$ of monomer 2. Finally, by a homogenizer (T10, IKa Labortechnik, Germany) the mixture of the organic phase and first aqueous phase was homogenized at $25.000 \mathrm{rpm}$. After homogenization, $0.1 \mathrm{mmol}$ of the pre-complex was added to the mixture of the organic phase and first aqueous phase. The second aqueous phase was added to the mixture of first aqueous, and organic phase, then this mixture was stirred in a sealed cylindrical polymerization reactor. The heat of polymerization system was adjusted to $40^{\circ} \mathrm{C}$, and the reactor was magnetically stirred at $500 \mathrm{rpm}$ (Carousel 6 Plus Reaction Station TM, Germany). After adding sodium bisulfate $(115 \mathrm{mg})$ and ammonium persulfate $(125 \mathrm{mg}$ ) as initiators, polymerization was continued for $24 \mathrm{~h}$. The obtained $\mathrm{Cd}(\mathrm{II})$ ions imprinted pHEMAC based nanoparticles were washed with water and the mixture of alcohol/water for removing unreacted monomers, surfactant, and initiator. The washing procedure was done in several steps, each washing step was done by centrifuging of nanoparticles in water at $30.000 \mathrm{rpm}$ for $45 \mathrm{~min}$. (Beckman Coulter Optimum TM L-look Ultracentrifuge, USA). Finally, the deionized water containing $0.5 \%$ sodium azide was used for storing the nanoparticles at $4^{\circ} \mathrm{C}$. Synthesize of non-imprinted pHEMAC nanoparticles were done by applying the same procedure except the addition of precomplex (instead of $\mathrm{Cd}(\mathrm{II})-\mathrm{MAC}$ pre-complex, MAC was added to the organic phase).

\section{Characterization of $\mathrm{Cd}$ (II) lons Imprinted pHEMAC Based Nanoparticles}

Nanoparticles were characterized by Zetasizer (Nano S, Malvern Instruments, London, UK), Fourier-transform infrared spectroscopy (FTIR) (Thermo Fisher Scientific, Nicolet iS10, Waltham, MA, USA) and Transmission electron microscopy TEM (FEl, Tecani G2 F30, Oregon, USA). Density and refraction index of deionized water for characterization analysis is $1.00 \mathrm{~g} / \mathrm{mL}$ and 1.33 , respectively. The light scattering of zetasizer instrument was adjusted at an incidence angle of $90^{\circ}, 25^{\circ} \mathrm{C}$. TEM analysis was done by dropping nanoparticles onto carbon coated copper grid and then dried at $25^{\circ} \mathrm{C}$. TEM photographs were taken at $200 \mathrm{kV}$ by TEM microscope.

The surface area of $\mathrm{Cd}(\mathrm{II})$ ions imprinted pHEMAC nanoparticles were calculated as follows:

$N=\left(6 \times 10^{10} . S\right) /\left(\Pi . \rho s . d^{3}\right)$

Where $\mathrm{N}$ indicates the number of nanoparticles per one milliliter, $\mathrm{S}$ is the $\%$ of solids, $\rho s$ is the density of bulk nanoparticles $(\mathrm{g} / \mathrm{mL})$, and $\mathrm{d}$ is the diameter $(\mathrm{nm})$. The density of nanoparticles was determined from mass-volume graph of nanoparticles. By these data, specific surface area of the nanoparticles was calculated by multiplying $\mathrm{N}$ with the surface area of 1 nanopolymer.

\section{Removal of Cd(II) lons from Cd(II) lons Imprinted pHEMAC Nanoparticles}

$\mathrm{HNO}_{3}$ solution (0.1 M) was used as a desorption agent for removing of $\mathrm{Cd}(\mathrm{II})$ ions from $\mathrm{Cd}(\mathrm{II})$ ions imprinted pHEMAC nanoparticles. For desorption of $\mathrm{Cd}(\mathrm{II})$ ions from nanoparticles, nanoparticles were added to $20 \mathrm{~mL}$ of desorption solution, 
then stirred in shaking bath (200 rpm) at $25^{\circ} \mathrm{C}$. For separating nanoparticles, this mixture was centrifuged at $30.000 \mathrm{rpm}$ for $45 \mathrm{~min}$, then these nanoparticles were dispersed in stocking solution. Removing of $\mathrm{Cd}(\mathrm{II})$ ions from $\mathrm{Cd}(\mathrm{II})$ ions imprinted pHEMAC nanoparticles were tested by ICP-AAS (Analyst 800, Perkin-Elmer, USA).

\section{Imprinting Factor}

The imprinting factor (IF) is the most commonly used term for describing the performance of an imprinting process. Adsorption capacities of $\mathrm{Cd}(\mathrm{II})$ ions imprinted and non-imprinted pHEMAC nanoparticles in different concentration of $\mathrm{Cd}(\mathrm{II})$ ions were measured. The first capacity coefficient for $\mathrm{Cd}(\mathrm{II})$ ions imprinted and non-imprinted pHEMAC nanoparticles and then, imprinting factor was calculated.

$(I F)=K_{d(M I P) /} K_{d(N I P)}$

\section{Test Matrices}

The simulated gastric fluid (SGF) was prepared according to the recommendations of the U.S. Pharmacopeia for drug dissolution studies in the stomach $(0.03 \mathrm{M} \mathrm{NaCl}, 0.085 \mathrm{M} \mathrm{NaCl}$, and $32 \%$ $(\mathrm{v} / \mathrm{w})$ pepsin, $\mathrm{pH}: 1.15)$. The artificial gastric fluid was used in batch metal sorption experiments and the adsorption studies evaluated by this fluid to test the application of this method in the gastric fluid.

\section{Distribution Coefficient $\left(K_{d}\right)$}

$K_{d}$ is the affinity of a sorbent for a target ion or molecule, here $\mathrm{Cd}(\mathrm{II})$ ions. $\mathrm{K}_{\mathrm{d}^{\prime}}(\mathrm{mL} / \mathrm{g})$ is a mass weighted partition coefficient between the solid phase and the liquid phase:

$K_{d}=\left[\left(C_{i}-C_{f}\right) / C_{f}\right] V / m$

where $C_{i}$ and $C_{f}$ are initial and final concentrations of metal ions in solution, respectively, $\mathrm{V}$ is the volume of the solution $(\mathrm{mL})$, and $\mathrm{m}$ is the mass of the sorbent $(\mathrm{g})$. $\mathrm{K}_{\mathrm{d}}$ measurements in simulated gastric fluid (SGF) were done with both $\mathrm{Cd}(\mathrm{II})$ ions imprinted and non-imprinted pHEMAC nanoparticles. For this purpose, $20 \mathrm{~mL}$ simulated gastric fluid (SGF) was prepared, then $\mathrm{Cd}(\mathrm{II})$ ions were added from nitrate salt to obtain $50 \mu \mathrm{g} / \mathrm{L}$ solution of this salt, finally, $0.202 \mathrm{gr}$ of $\mathrm{Cd}(\mathrm{II})$ ions imprinted PHEMAC nanoparticles were added to the solution. Another time this experiment was done with non-imprinted pHEMAC nanoparticles.

\section{Adsorption of Cd(II) lons by $\mathrm{Cd}(\mathrm{II})$ lons Imprinted pHEMAC Nanoparticles}

The adsorption of $\mathrm{Cd}(\mathrm{II})$ ions with $\mathrm{Cd}(\mathrm{II})$ ions imprinted pHEMAC nanoparticles was studied in a batch experimental system. Therefore, 0.202 gr of $\mathrm{Cd}(\mathrm{II})$ ions imprinted pHEMAC nanoparticles were added to $20 \mathrm{~mL}$ aqueous solution of $\mathrm{Cd}\left(\mathrm{NO}_{3}\right)_{2}$ and stirred with the rate of $200 \mathrm{rpm}$ at $25^{\circ} \mathrm{C}$ for $1 \mathrm{~h}$, then nanoparticles were centrifuged $(30.000$ rpm for $45 \mathrm{~min}$ ) and then, the concentration of aqueous phase was determined. ICP-ASS method (Analyst 800, Perkin-Elmer, USA) was applied for the determination of an initial, and final concentration of $\mathrm{Cd}(\mathrm{II})$ ions. Then Equation 3 was used for calculating amount of adsorbed Cd(II) ions. The effect of some parameters as $\mathrm{pH}$, initial concentration of $\mathrm{Cd}(\mathrm{II})$ ions, the temperature in adsorption of $\mathrm{Cd}(\mathrm{II})$ ions by $\mathrm{Cd}(\mathrm{II})$ ions imprinted pHEMAC nanoparticles was studied. All of the experiment was done two times and the difference in the results was less than $5 \%$.

$Q=\left[\left(C_{0}-C_{i}\right) \cdot V\right] / m$

\section{Selectivity Studies}

The selectivity and specificity of $\mathrm{Cd}(\mathrm{II})$ ions imprinted and non-imprinted pHEMAC nanoparticles for $\mathrm{Cd}(\mathrm{II})$ ions were determined in this study. For this purpose, $\mathrm{Cd}(\mathrm{II})$ ions imprinted and non-imprinted pHEMAC nanoparticles were interacted with cadmium, copper, zinc, nickel, and lead ions in a batch system. The selectivity of $\mathrm{Cd}(\mathrm{II})$ ions imprinted pHEMAC nanoparticles for $\mathrm{Cd}(\mathrm{II})$ ions was evaluated with competitive ions (cadmium, zinc, nickel, and lead ions). Then $k$ of non-imprinted nanoparticles for $\mathrm{Cd}(\mathrm{II})$ ions respect to copper, zinc, nickel, and lead were measured. Finally, relative selectivity coefficients $\left(k^{\prime}\right)$ of nanoparticles were calculated.

\section{RESULTS and DISCUSSIONS Characterization of Nanoparticles}

Characterization of $\mathrm{Cd}(\mathrm{II})$ ions imprinted PHEMAC nanoparticles was done by the zetasizer, FTIRATR and TEM. The average size and polydispersity index (PDI) of these nanoparticles is 44.43 
$\mathrm{nm}$ and 0.064 . As seen from the figure $1 \mathrm{~A}$, the nanoparticles have a narrow size distribution, that's why polymerization method and a recipe is suitable for synthesizing monosize nanoparticles. As seen in TEM photograph, each of the nanoparticles has spherical shape and size around $50 \mathrm{~nm}$ (1B). Also, characterization studies of $\mathrm{Cd}(\mathrm{II})$ ions imprinted PHEMAC nanoparticles were done by using FTIR-ATR in the wavenumber range of $400-4000 \mathrm{~cm}^{-1}$ (Thermo Fisher Scientific, Nicolet iS10, Waltham, MA, USA). As shown in the Figure 1.C, FTIR spectra of nanoparticles have a broad peak in $3200-3500 \mathrm{~cm}^{-1}$ that consists of several sharp peaks as the stretching vibration bands of hydrogen bonded alcohol (HEMA), at around 3200 and $(-\mathrm{CONH}-)$ at around $3300 \mathrm{~cm}^{-1}(\mathrm{MAC})$. The characteristic $(\mathrm{C}-\mathrm{O})$ and $(\mathrm{C}-\mathrm{H})$ stretching vibration bands of the p(HEMA)-EGDMA are observed at 1720 and $2930 \mathrm{~cm}^{-1}$, respectively. Also have peaks around at $600-880 \mathrm{~cm}^{-1}$ that indicate (C-S) group in MAC, indicating the incorporation of MAC into the structure.

Nanoparticles have large specific surface area and therefore are suitable for adsorbing of molecules and $\mathrm{Cd}(\mathrm{II})$ ions. The surface area of this nanoparticles is large $\left(2460 \mathrm{~m}^{2} / \mathrm{g}\right)$.

\section{Measurement of $K_{d}$ for Cd(II) lons Imprinted and Non-Imprinted pHEMAC Nanoparticles}

$\mathrm{K}_{\mathrm{d}}$ measurement, for adsorption $\mathrm{Cd}(\mathrm{II})$ ions from simulated gastric fluid (SGF) with $\mathrm{Cd}$ (II) ions imprinted and non-imprinted nanoparticles were calculated. The affinity coefficients $\left(K_{d}\right)$ of $\mathrm{Cd}(\mathrm{II})$ ions imprinted and non-imprinted nanoparticles are $993.9 \mathrm{~mL} / \mathrm{g}$ and $134.6 \mathrm{~mL} / \mathrm{g}$ respectively. The amount of affinity coefficient for $\mathrm{Cd}(\mathrm{II})$ ions imprinted nanoparticles at least is seven times higher than non-imprinted nanoparticles. As seen, the affinity and selectivity of $\mathrm{Cd}(\mathrm{II})$ ions imprinted
A

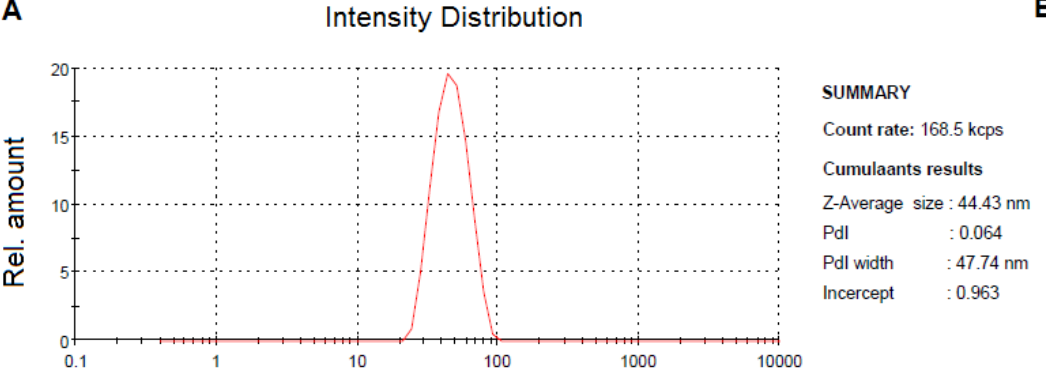

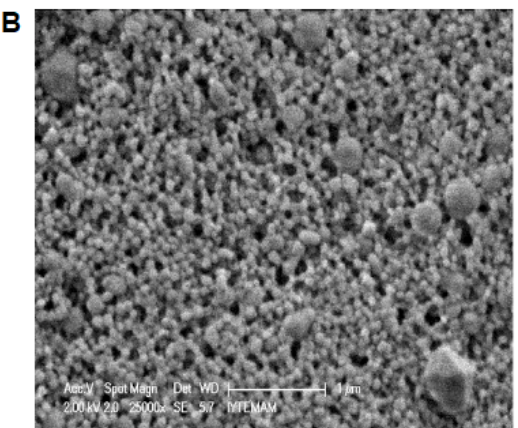

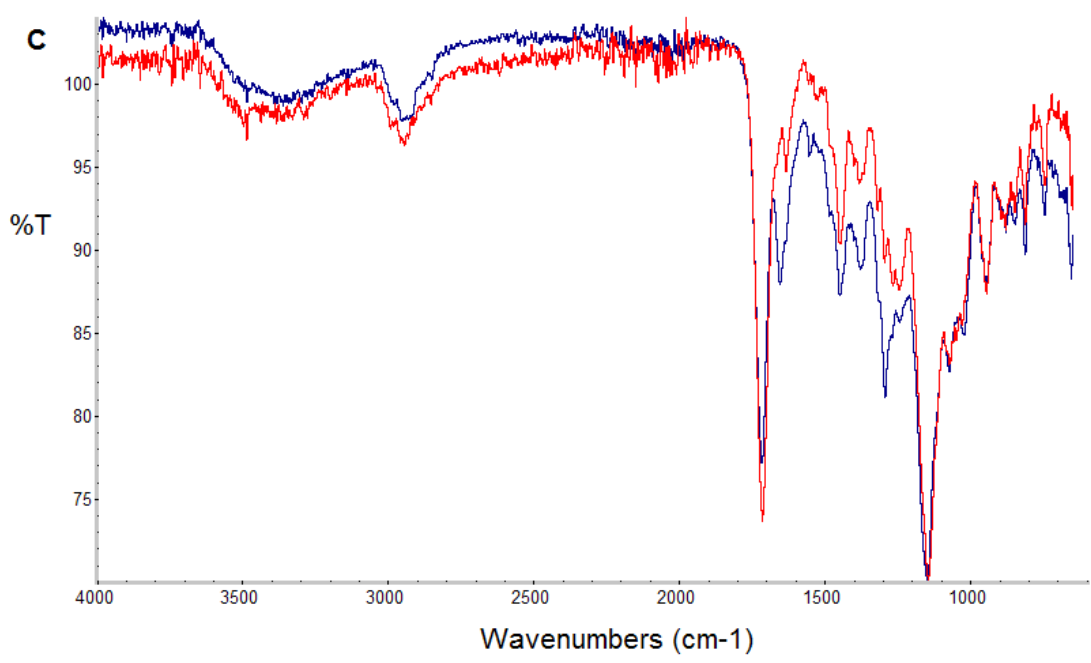

Figure 1. Zeta-size (A), TEM image (B) and FTIR spectra (C) of Cd(II) ions imprinted pHEMAC nanoparticles. 
nanoparticles for $\mathrm{Cd}(\mathrm{II})$ ions is larger than nonimprinted nanoparticles.

\section{Imprinting Factor}

Kinetic analysis of $\mathrm{Cd}(\mathrm{II})$ ions was performed with $\mathrm{Cd}(\mathrm{III}$ ions imprinted and non-imprinted pHEMAC SPR nanosensors in aqueous solution in real time (Figure 2). As seen, the adsorption capacity of $\mathrm{Cd}(\mathrm{II})$ ions imprinted pHEMAC nanoparticles is higher than non-imprinted PHEMAC nanoparticles. The capacity coefficients for $\mathrm{Cd}(\mathrm{II})$ ions imprinted and non-imprinted pHEMAC nanoparticles are 147.06 and 102.75, respectively. Therefore, imprinting factor of this study is 1.43 that represent imprinting nanoparticles are suitable for this adsorption.

\section{Adsorption of $\mathrm{Cd}(\mathrm{II})$ lons by $\mathrm{Cd}(\mathrm{II})$ lons Imprinted pHEMAC Nanoparticles}

These adsorption studies were done in different $\mathrm{pHs}$, temperatures and various initial concentrations of $\mathrm{Cd}\left(\mathrm{NO}_{3}\right)_{2}$, for determining conditions of maximum adsorption of $\mathrm{Cd}(\mathrm{II})$ ions by $\mathrm{Cd}(\mathrm{II})$ ions imprinted pHEMAC nanoparticles. The effect of medium $\mathrm{pH}$ on $\mathrm{Cd}(\mathrm{II})$ ions adsorption is shown in Figure 3. As expected, the adsorption amount of metal ions decreases with decreasing $\mathrm{pH}$ because of the functional group existing in the amino acid based monomer (thiol group). These thiol groups are more protonated hence, they are less available for metal ions. Initially, the rate of ion adsorption was very fast, but then it slowed down and reached to equilibrium. The time of reaching to adsorption equilibrium is a kinetics controlled process completely. This condition doesn't be related proportionally with the complex formation constant.

The adsorption capacity of $\mathrm{Cd}(\mathrm{II})$ ions imprinted pHEMAC nanoparticles for $\mathrm{Cd}(\mathrm{II})$ ions was decreased by increasing temperature of medium. The decreasing of adsorption capacity with increasing temperature is because of interaction

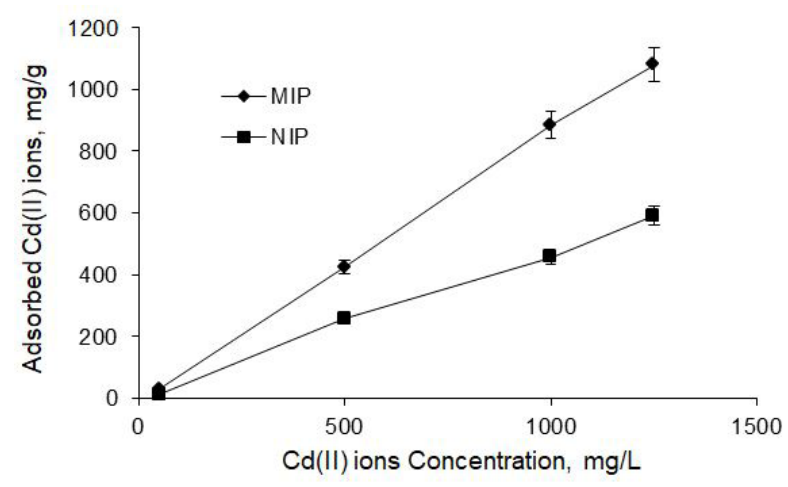

Figure 2. Comparison of adsorption capacity for $\mathrm{Cd}(\mathrm{II})$ ions imprinted and non-imprinted pHEMAC nanoparticles.

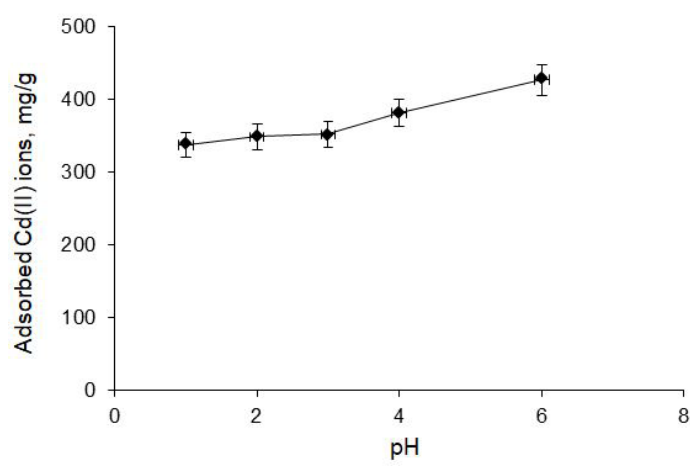

Figure 3. The effect of medium $\mathrm{pH}$ on adsorption of $\mathrm{Cd}(\mathrm{II})$ ions by $\mathrm{Cd}(\mathrm{II})$ ions imprinted pHEMAC nanoparticles, $\mathrm{C}$ : 500 $\mathrm{mg} / \mathrm{L}$, t: $60 \mathrm{~min}, \mathrm{~T}: 25^{\circ} \mathrm{C}$. 
between a functional group of amino acid monomer (MAC) and $\mathrm{Cd}(\mathrm{II})$ ions. The cysteine in MAC forms with $\mathrm{Cd}(\mathrm{II})$ ions was coordinated by covalent bond. The adsorption capacity of $\mathrm{Cd}(\mathrm{II})$ ions imprinted pHEMAC nanoparticles for $\mathrm{Cd}(\mathrm{II})$ ions was 448.1 $\mathrm{mg} / \mathrm{g}$ at $4^{\circ} \mathrm{C}$, and $397.25 \mathrm{mg} / \mathrm{g}$ in $40^{\circ} \mathrm{C}$ (Figure 4 ).

The adsorption of $\mathrm{Cd}(\mathrm{II})$ ions by $\mathrm{Cd}(\mathrm{II})$ ions imprinted pHEMAC nanoparticles was examined in the various initial concentration of $\mathrm{Cd}(\mathrm{II})$ (Figure 5). The amount of adsorbed $\mathrm{Cd}(\mathrm{II})$ ions is a function of initial concentration was estimated as expected. Initially, rate of adsorption is very fast, and then adsorption rate slows down because of filling of cavities ( $\mathrm{Cd}(\mathrm{II})$ ions imprinted regions), and remain constant. Adsorption capacities of $\mathrm{Cd}(\mathrm{II})$ ions imprinted pHEMAC nanoparticles are $33.5(\mathrm{mg} / \mathrm{g})$ and $1381.3(\mathrm{mg} / \mathrm{g})$ in $50(\mathrm{mg} / \mathrm{L})$ and $2000(\mathrm{mg} / \mathrm{L})$ of initial concentration.

\section{The Thermodynamic Isotherms}

By using these adsorption data, Langmuir and
Freundlich isotherms for $\mathrm{Cd}(\mathrm{II})$ ions imprinted pHEMAC nanoparticles were applied, represented as following equations, Equations. (5) and (6), respectively [12].

$Q=Q_{\max } \cdot b \cdot C_{e q} /\left(1+b C_{e q}\right)$

$Q_{\text {eq }}=K_{F} \cdot C_{e q}^{1 / n}$

Langmuir and Freundlich adsorption isotherm models were calculated by using experimental results and adsorption parameters were given Table 1 and Figure 6 . The Langmuir model describes that binding sites distribute homogeneous. The Freundlich model is based on a heterogeneous layer of a surface. According to $\mathrm{R}^{2}$ and $\mathrm{Q}_{\max }$ values; Langmuir adsorption model was supported by experimental results.

The correlation coefficient, $R^{2}$ values and the constants obtained from the Langmuir and Freundlich isotherms $\left(b, R_{L}, K_{F}, 1 / n\right)$ which applied

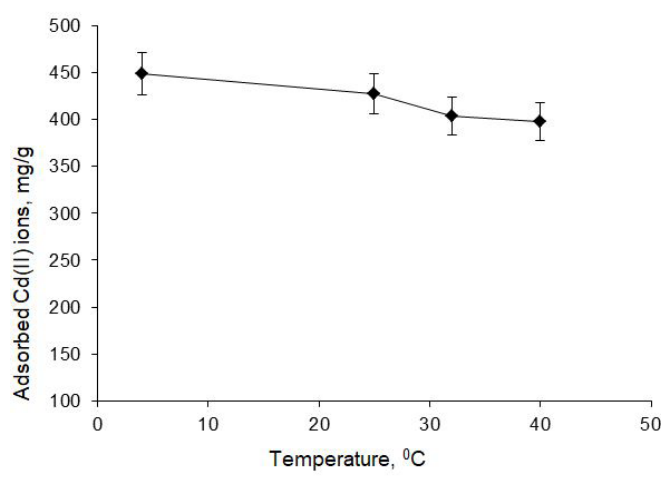

Figure 4. The effect of medium temperature on adsorption of $\mathrm{Cd}(\mathrm{II})$ ions by $\mathrm{Cd}(\mathrm{II})$ ions imprinted pHEMAC nanoparticles, C: $500 \mathrm{mg} / \mathrm{L}, \mathrm{t}: 60 \mathrm{~min}, \mathrm{pH}: 6.0$.

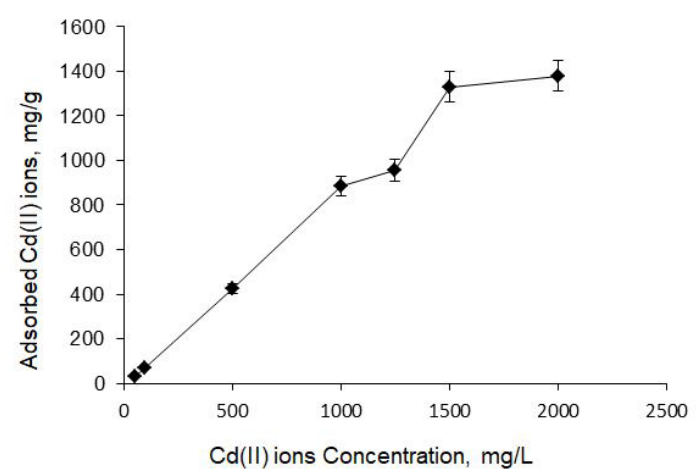

Figure 5. The effect of temperature on adsorption of $\mathrm{Cd}(\mathrm{II})$ ions by $\mathrm{Cd}(\mathrm{II})$ ions imprinted pHEMAC nanoparticles, t: 60 min; $\mathrm{pH}: 6 ; \mathrm{T}: 25^{\circ} \mathrm{C}$. 

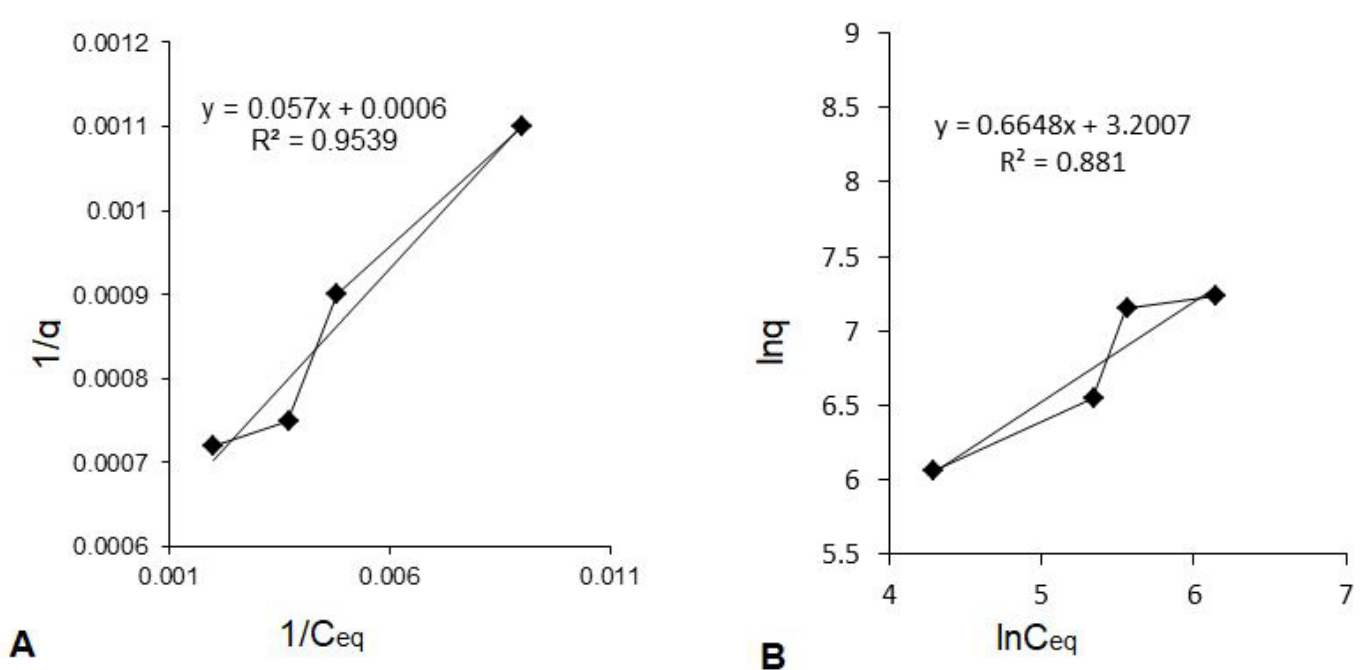

Figure 6. Langmuir (A) and Freundlich (B) isotherm for adsorption of $\mathrm{Cd}(\mathrm{II})$ ions by $\mathrm{Cd}(\mathrm{II})$ ions imprinted pHEMAC nanoparticles.

Table 1. Parameters of Langmuir and Freundlich models.

\begin{tabular}{ll}
\hline \multicolumn{1}{c}{ Langmuir } & Freundlich \\
\hline$Q_{\max }(\mathrm{mg} / \mathrm{L}): 1666.7$ & $1 / \mathrm{n}: 0.665$ \\
\hline $\mathrm{B}(\mathrm{mL} / \mathrm{mg}): 0.01$ & $\mathrm{~K}_{\mathrm{f}}(\mathrm{mL} / \mathrm{mg}): 24.55$ \\
& \\
$\mathrm{R}^{2}: 0.954$ & $\mathrm{R}^{2}: 0.881$ \\
\hline $\mathrm{R}_{\mathrm{L}}: 0.17$ & \\
\hline
\end{tabular}

for adsorption of cadmium ions on the ion imprinted nanoparticles are summarized in Table 1.

The Langmuir model gives the higher $\mathrm{R}^{2}$ values which are 0.954 compared to Freundlich model which is 0.881 , therefore that shows adsorption of cadmium ions on the ion imprinted nanoparticles is best described by Langmuir model. Also, the $R_{L}$ values are between 0 and 1 , indicating that the adsorption of $\mathrm{Cd}(\mathrm{II})$ ions on the $\mathrm{Cd}(\mathrm{II})$ ions imprinted pHEMAC nanoparticles is favorable at the conditions being studied and fitted to Langmuir model. Theoretical $Q_{\max }$ and experimental $Q_{\max }$ are 1666.7 (mg/L) and 1377.9 (mg/L), respectively. The $1 / \mathrm{n}$ values obtained from the Freundlich model are below one but are close to one, therefore these adsorptions are homogeneous and monolayer. In this study, the results indicate that the Langmuir model gave a better fit than the Freundlich model.
The $1 / \mathrm{n}$ value obtained from the Freundlich model is below one (0.665). We can say, adsorption is more homogeneous and monolayer. Also, the results indicate that the Langmuir model gives a better fit than the Freundlich model.

\section{Selectivity Coefficient}

A solution containing 500 ppm of all five metal ions (cadmium, copper, lead, nickel, and zinc ions) at a constant $\mathrm{pH}$ (6) and at $25^{\circ} \mathrm{C}$ was incubated with $\mathrm{Cd}(\mathrm{II})$ ions imprinted and non-imprinted pHEMAC nanoparticles in a batch system. The selectivity coefficients $\left(k_{d}\right)$ of $\mathrm{Cd}(\mathrm{II})$ ions imprinted and non-imprinted pHEMAC nanoparticles for $\mathrm{Cd}(\mathrm{II})$ ions respect to copper, zinc, nickel and lead ions were calculated, then relative selectivity coefficients $\left(k^{\prime}\right)$ were calculated. Adsorption values are given in Table 2, as seen adsorption 
Table 2. $\left(k_{d}\right)$, and $k^{\prime}$ values of $C d(I I)$ ions imprinted and non-imprinted pHEMAC nanoparticles for Cd(II) ions respect to $\mathrm{Cu}(\mathrm{II}), \mathrm{Zn}(\mathrm{II}), \mathrm{Ni}(\mathrm{II})$ and $\mathrm{Pb}(\mathrm{II})$ ions.

\begin{tabular}{cccccc}
\hline & MIP & \multicolumn{2}{c}{ NIP } & & \\
Metal lons & Q & $k_{d}$ & $Q$ & $k_{d}$ & $k^{\prime}$ \\
\hline $\mathrm{Cd}(\mathrm{II})$ & 392183.5 & - & 166956.5 & - & - \\
\hline $\mathrm{Cu}(\mathrm{II})$ & 132131.2 & 2.97 & 135720.0 & 1.20 & 2.50 \\
\hline $\mathrm{Zn}$ (II) & 211012.0 & 1.80 & 104347.0 & 1.60 & 1.13 \\
\hline $\mathrm{Ni}$ (II) & 109523.9 & 3.50 & 70460.0 & 2.20 & 1.60 \\
\hline $\mathrm{Pb}$ (II) & 89666.0 & 4.30 & 91453.0 & 1.70 & 2.50 \\
\hline
\end{tabular}

of $\mathrm{Cd}(\mathrm{II})$ ions was higher than adsorption of other ions, also selectivity coefficient of $\mathrm{Cd}(\mathrm{II})$ ions imprinted pHEMAC nanoparticles is higher than non-imprinted nanoparticles. These amount of $k_{d}$ for $\mathrm{Cd}(\mathrm{II})$ ions imprinted in comparison non-imprinted $(392183.5,166956.5)$ indicates $\mathrm{Cd}(\mathrm{II})$ ions imprinted PHEMAC nanoparticles are more selective than non-imprinted pHEMAC nanoparticles, also the amount of relative selectivity coefficients $\left(k^{\prime}\right)$ indicate the selective adsorption of $\mathrm{Cd}(\mathrm{II})$ ions imprinted pHEMAC nanoparticles to the non-imprinted pHEMAC nanoparticles. When this value is compared with the single system (non-competitive system) this adsorption amount was lower than the single system, which means that antagonistic effect was observed in this adsorption system.

\section{CONCLUSION}

$\mathrm{Cd}(\mathrm{II})$ ions imprinted pHEMAC nanoparticles have unique physical and chemical properties as high surface area and high selectivity, that's why these materials have been used as an adsorbent material for adsorption of molecules and ions. In this study, our purpose is design and preparation of $\mathrm{Cd}(\mathrm{II})$ ions imprinted PHEMAC based nanoparticles as a drug for treatment specific heavy metal detoxification. These nanoparticles because of their high surface area and high selectivity have great potential for the adsorption and separation of specific unwanted heavy metal ions from liquid medium (gastric fluid). In this study, the maximum adsorption capacity of $\mathrm{Cd}(\mathrm{II})$ ions by $\mathrm{Cd}(\mathrm{II})$ ions imprinted pHEMAC based nanoparticles was $448.1 \mathrm{mg} / \mathrm{g}$ in $4^{\circ} \mathrm{C}$. Compared to other studies [1119] these nanoparticles have higher adsorption capacities.

\section{References}

1. Agency for Toxic Substances and Disease Registry, http://www.atsdr.cdc.gov/csem/, 36.

2. T. Li, Q. Chang, X. Yuan, J. Li, GA. Ayoko, R.L. Forst, H. Chen, X. Zhang, Y. Song, W. Song, Cadmium transfer from contaminated soils to the human body through rice consumption in southern Jiangsu Province, China, Environ. Sci., 19 (2017) 843-850.

3. W.S. Zhong, T. Ren, L.J. Zhao, Determination of $\mathrm{Pb}$ (lead), Cd (cadmium), Cr (chromium), Go (Gopper), $\mathrm{Ni}$ (nickel) in Chinese tea with high-resolution continuum source graphite furnace atomic absorption spectrometry, J. Food and Drug Analy., 24, (2016) 4655.

4. T. Caciari, A. Sancini, F. Tomei, L. Antetomaso, G. Tomei, B. Scala, F. Sinibaldi, D.C. Pastena, G. Andreozzi, N. Nardone, M.P. Schifano, P. Corbosiero, A. Capozzella, DS. Sio, M. Ciarrocca, Cadmium blood/urine levels and blood pressure in workers occupationally exposed to urban stressor, Ann. Ig., 24 (2012) 417-28.

5. A. Pizent, B., Tariba, T. Živkovi, Reproductive toxicity of metals in men, Arh. Hig. Rada. Toksikol., 63 (2012) 1-35.

6. C. Ciobanu, B.G. Slencu, R. Cuciureanu, Estimation of dietary intake of cadmium and lead through food consumption, Rev. Med. Chir. Soc. Med. Nat. Iasi., 2, (2012) 617-23.

7. L. Evrenoglou, SA. Partsinevelou, P. Stamatis, A. Lazaris, E. Patsouris, C. Kotampasi, SP. Nicolopoulou, Children exposure to trace levels of heavy metals at the north zone of Kifissos River, Sci. Total. Environ., 443 (2013) 650-661.

8. W. Qu, E.J. Tokar, A.J. Kim A.J, MW. Bell, M.P. Waalkes, Chronic cadmium exposure in vitro causes acquisition of multiple tumor cell characteristics in human pancreatic epithelial cells, Environ. Health Perspect., 120 (2012) 1265-1271.

9. H. Sun, F. Qiao, G. Liu, S. Liang, Simultaneous isolation of six fluoroquinolones in serum samples by selective molecularly imprinted matrix solid-phase dispersion, Anal. Chim. Acta, 625 (2008) 154-159. 
10. M. Andac, S. Mirel, S. Senel, R. Say, A. Ersoz, A. Denizli, Ion-imprinted beads for molecular recognition based mercury removal from human serum, Int. J. Biol. Macromol., 40 (2007) 159-166.

11. L. Chen, S. Xu, Sh., J. Li, Recent advances in molecular imprinting technology: current status, challenges and highlighted applications, Chem. Soc. Rev., 40 (2011) 2922-2942.

12. E.H. Ibrahim, A. Denizli, S. Bektas, O. Genc, E. Piskin, Cadmium removal from human plasma by cibacron blue F3GA and thionein incorporated into polymeric microsphere, J. Chromatogr. B, 720 (1998) 217-224.

13. M. Andac, R. Say, A. Denizli, Molecular recognition based cadmium removal from human plasma, J. Chromatogr. B, 811 (2004) 119-126.

14. S. Asir. L. Uzun. D. Turkmen. R. Say. A. Denizli, IonSelective imprinted superporous monolith for cadmium removal from human plasma, Separ. Sci. Technol., 40 (2005) 3167-3185.
15. A. Kara, L. Uzun, N. Bereli, A. Denizli, Poly (ethylene glycol dimethacrylate-n-vinyl imidazole) beads for heavy metal removal, J. Hazar., 106 (2004) 93-99.

16. L. Uzun, A. Kara, N. Tuzmen, A. Karabakan, Synthesis and characterization of poly (ethylene glycol dimethacrylate-1-vinyl-1,2,4-triazole) copolymer beads for heavy-metal removal, J. Appl. Poly. Sci., 102 (2006) 4276-4283.

17. M. Jalilzadeh, L. Uzun, S. Senel, A. Denizli, Specific heavy metal ion recovery with ion-imprinted cyrogels, J. Appl. Poly. Sci., 133 (2016) 43095-43104.

18. G. Sener, E. Ozgur, E. Yılmaz, L. Uzun, R. Say, A. Denizli, Quartz crystal microbalance based nanosensor for lysozyme detection with lysozyme imprinted nanoparticles, Biosens. Bioelectron. 26 (2010) 815-821.

19. M. Uygun, D.A. Uygun, E. Özçalışkan, S. Akgöl, A. Denizli, Concanavalin A immobilized poly(ethylene glycol dimethacrylate) based affinity cryogel matrix and usability of invertase immobilization, J. Chromatogr. B, 73 (2012) 887-888. 